\title{
Causes, sign and symptoms of malnutrition among the children.
}

\author{
Alamgir Khan ${ }^{1 *}$, Salahuddin Khan ${ }^{1}$, Syed Zia-ul-Islam', Abdul Manan Tauqeer², Riffat ${ }^{2}$, Manzoor Khan ${ }^{3}$ \\ ${ }^{1}$ Department of Sports Science and Physical Education, Gomal University, KP, Pakistan \\ ${ }^{2}$ Department of Economics, Gomal University, KP, Pakistan \\ ${ }^{3}$ Faculty of Education, Hazara University, Manshera, KP, Pakistan
}

\begin{abstract}
The present review study was an effort to assess the perception of various researchers (Available in the form of literature) regarding the causes, sign, symptoms, and effects of malnutrition on human health. Various research articles congregated for the purpose to review the perceptions of different researchers regarding the causes, sign and symptoms and effects of malnutrition on the health of children. After study the perception of different researchers available in the form of literature, the researcher arrived at conclusion that unbalance diet, psychological problems, digestive syndromes and stomach conditions etc all are the causes of malnutrition. It also concluded by the researcher from the available literature, that loss of fat, difficulty in respiration, and complication during surgery are the main sign and symptoms of malnutrition. Furthermore, under nutrition can lead the body toward weakness and over nutrition lead the body toward obesity.
\end{abstract}

Keywords: Diet, Nutrition, Malnutrition, Sign and symptoms, Health.

\section{Background of the Study}

Pakistan has a frighteningly high level of malnutrition and $24 \%$ of the total population is undernourished. According to United Nations Food and Agriculture Organization (FAO, 2015) in Pakistan a very huge number of population are not receiving proper nourishment. FAO (2015) further investigated that the issue of malnutrition is complex and widespread and similarly many of health problems among the people of Pakistan is due to malnutrition.

A very huge number of masses affected due to malnutrition in not only developing countries but also affect millions of masses in developed countries, such as UK, USA and China etc. It is commonly found among those peoples having health problems, social problems and physical damage such as injury or burns etc. [1].

Growth and development is directly correlated with diet and nutrition used by a person. Use of balance diet helps one to stay healthy and to perform the social activities in beneficial manner. Lack of balance diet has adverse effect on overall structural and functional capacity of then body [2].

As result of all the above discussion, now it is clear that malnutrition totally affects the performance of a person. For the purpose to know that what are the effects of malnutrition on human health and what are the sign and symptoms of malnutrition, the researcher intended to evaluate the perceptions of various researchers under the title "causes, sign and symptoms of malnutrition among the children".

\section{Research Based Evidences Regarding Diet, Nutrition and Malnutrition}

Diet, nutrition and malnutrition are commonly used terminologies but no one can clearly differentiate it. The following research evidences regarding diet, nutrition and malnutrition will easily help one to understand the difference between diet, nutrition and malnutrition.

\section{Diet}

Diet refers to the use and collection of such type of food ingredients which allow growth and maintain the various physiological functions of the body [3]. Use of diet depends upon the age, sex and nature of activity performing by a person.

\section{Nutrition}

Nutrition is a process of getting energy from the food that we eat. The energy that we get from the food helps the body to allow growth and maintain the body functions. According to US [4] "Nutrition is the science that interprets the interaction of nutrients and other substances in food in relation to maintenance, growth, reproduction, health and disease of an organism. It includes food intake, absorption, assimilation, biosynthesis, catabolism and excretion"

[5] stated that use of diet depend upon the age, sex and nature of activity. Similarly, an athlete needs to utilize different food ingredients before, during and after the activity. Diet may be given to athlete according to the nature and type of activity. The following few tables shows the intake of diet for different sports events (Tables 1a-1d).

\section{Nutrients}

According to [6] nutrients found in all foods and drinks provide nourishment for the body such as

1. Materials which provide energy 
Citation: Khan A, Khan S, Zia-ul-Islam S, et al. Causes, sign and symptoms of malnutrition among the children. J Nutr Hum Health. 2017;1(1):24-27.

Table 1a. Showing the recommended nutrients for short duration events players.

\begin{tabular}{|c|c|}
\hline Nutrients & Percentage (\%) \\
\hline Carbohydrates & 60 \\
\hline Proteins & $15-25$ \\
\hline Fats & $15-25$ \\
\hline
\end{tabular}

Table 1b. Showing the recommended Nutrients for Moderate duration events players.

\begin{tabular}{|c|c|}
\hline Nutrients & Percentage (\%) \\
\hline Carbohydrates & $60-70$ \\
\hline Proteins & $10-15$ \\
\hline Fats & $20-30$ \\
\hline
\end{tabular}

Table 1c. Showing the recommended Nutrients for long duration events players.

\begin{tabular}{|c|c|}
\hline Nutrients & Percentage (\%) \\
\hline Carbohydrates & $60-70$ \\
\hline Proteins & $10-15$ \\
\hline Fats & $20-30$ \\
\hline
\end{tabular}

Table 1d. Showing the recommended Nutrients for long duration events players.

\begin{tabular}{|c|c|}
\hline Nutrients & Percentage (\%) \\
\hline Carbohydrates & $60-70$ \\
\hline Proteins & $10-15$ \\
\hline Fats & $20-30$ \\
\hline
\end{tabular}

2. Building blocks for bone, muscle, organs, hormones and blood

3. Materials which protect the body

4. Maintain and regulate the body temperature

Daily intake of food varies from person to person. [6] suggested the daily intake of some major or macronutrients nutrients (Table 2).

According to [7] "malnutrition is the result of an insufficient supply of nutrients due to impaired metabolism, malabsorption or an inadequate supply of food". Malnutrition may be defined as underweight, is a serious public-health problem that has been linked to a substantial increase in the risk of mortality and morbidity. Women and young children bear the brunt of the disease burden associated with malnutrition [8].

According to the World Health Organization (WHO), malnourishment is the serious sole risk to worldwide public health. Malnutrition refers to both under nutrition (sub nutrition) and over nutrition.in other words we can explain the malnutrition as the inadequate, high or improper use of nutrients. Human body need to utilize all component of diet in a right amount. Lacking of balance or sufficient diet unfavorably affects the whole functional capacity of the body [9]. The author further elaborated the two categories of malnutrition as

Table 2. showing the daily-recommended intake of major nutrients for adults.

\begin{tabular}{|c|c|}
\hline Nutrients & Daily intake for adult \\
\hline Fats & Recommended intake of fat for an average adult is $70 \mathrm{~g}$ \\
\hline Protein & Recommended intake of protein for an average adult is $50 \mathrm{~g}$ \\
\hline Carbohydrates & $\begin{array}{l}\text { Recommended intake of carbohydrates (both complex and } \\
\text { simple) for an average adult is } 310 \mathrm{~g}\end{array}$ \\
\hline
\end{tabular}

Under nutrition: A person needs a right amount of calories on daily basis (calories depend upon the nature and type of the body). Some time we take nutrients, which do not provide calories according to the need of the daily activities and type a physique a person has. In such situations an Individuals are malnourished, or suffer from under nutrition.

Over nutrition: Taking too much calories also have negative effects and also cause different health problems. People are also malnourished, or suffer from over nutrition if they consume too many calories.

\section{Sign and symptoms of malnutrition}

According to [10] each deformity or abnormality has some sign and symptoms. Sign and symptoms give indication to the person that they have a problem. Malnutrition is deficiency caused by poor diet in term of under nutrition and over nutrition. According to [9] A symptom is something the patient feels and reports, while a sign is something other people, such as the doctor detect. For example, pain may be a symptom while a rash may be a sign. The author further elaborated the signs and symptoms of malnutrition as loss of fat (adipose tissue), breathing difficulties, a higher risk of respiratory failure, higher risk of complications after surgery, higher risk of hypothermia, abnormally low body temperature, higher susceptibility to feeling cold, longer healing times for wounds, longer recover times from infections, longer recovery from illnesses, lower sex drive, problems with fertility, reduced muscle mass, reduced tissue mass, fatigue, or apathy and irritability etc.

Malnutrition caused so many problems such as lower sex drive, reduction in muscles mass, obesity and improper functioning of body parts. Use of nutrition varies from person to person and activity to activity. It is necessary for an individual to use diet to his/her physique and concerned activity [11].

According to [1] following are common signs of malnutrition include:

1. Unintentional weight loss

2. Low body weight

3. Lack of interest in eating and drinking

4. Feeling of fatigue

5. Feeling weakness

6. Improper growth of Childs

\section{Causes of malnutrition}

Diet problems, psychological problems, digestive complaints and stomach conditions, lack of food, high food prices and lack of breastfeeding all the main causes of malnutrition [9]. The main causes of malnutrition include changes in nutrient requirements, secondary to disease processes and drug modalities in combination with low or marginal dietary intake. Infections are common and result in anorexia, poor dietary intake, and malnutrition, which predispose the patient to another infection [12]. 
The main causes of malnutrition among the children are insufficient intake of food and lack of nutritional knowledge. In child hood, majority of Childs have no knowledge about the daily caloric intake. As result, they lead to malnutrition [13].

\section{Treatments for malnutrition}

It is necessary for the health experts to provide treatment to the patient according to his/her general health and severity of the abnormality or deformity. According to [1] Treatment of a person with malnutrition depends on the person's general health and how severely malnourished they are.

The first dietary advice is usually:

1. Use foods that are high in calories and protein

2. Snacking between meals

3. Having drinks that contain lots of calories

4. Avoid Excessive intake of food

5. Use diet when needed

\section{Preventing malnutrition}

According to NHA (2015), [14] it is necessary for a person to avoid malnutrition and also to use all those food ingredients or healthy diet which promote his/her health. Healthy diet include to use

Plenty of fruit and vegetables

Plenty of bread, rice, potatoes, pasta and other starchy foods

Milk and dairy foods

Meat, fish, eggs, beans and other non-dairy sources of protein

\section{Malnutrition and its effects on the body}

According to [15] Malnutrition caused improper growth and development, weakness and different kind of abnormalities and deformities among the children. The author further classified the malnutrition adversely affect the health problems. These problems may be classified or categorized as

Short-term implications: In early childhood the child, grow so fast. Nutrient deficiencies can have short-term implications such as

- Improper functioning of immune system

- Improper growth of the body

Long-term implications: The short-term implications of malnutrition eventually give way to long-term complications, such as

- Slow body growth

- Slow cognitive development

\section{Presentation and Analysis of Previous Available Data (Table 3a, b)}

Table 3a. Showing the causes of malnutrition.

\begin{tabular}{|c|c|c|}
\hline Authors & Year & Results Regarding the causes of Malnutrition \\
\hline Christian & 2016 & $\begin{array}{l}\text { Poor diet, mental health problems, mobility problems, } \\
\text { digestive disorders and stomach conditions, } \\
\text { alcoholism etc. all are the causes of malnutrition }\end{array}$ \\
\hline Kerstetter et al. & 1992 & $\begin{array}{l}\text { Low or little intake of diet, use of drugs and health } \\
\text { problems, mobility problems, digestive disorders and } \\
\text { stomach conditions all are the causative agents of } \\
\text { malnutrition }\end{array}$ \\
\hline $\begin{array}{l}\text { Visvanathan and } \\
\text { Chapman }\end{array}$ & 2009 & $\begin{array}{l}\text { The main causes of malnutrition among the children } \\
\text { are insufficient intake of food and lack of nutritional } \\
\text { knowledge. In child hood, majority of Childs have no } \\
\text { knowledge about the daily caloric intake }\end{array}$ \\
\hline
\end{tabular}

Table 3b. Showing the sign and symptoms of malnutrition.

\begin{tabular}{|c|c|l|}
\hline Authors & Year & $\begin{array}{l}\text { Results Regarding the sign and symptoms of } \\
\text { Malnutrition }\end{array}$ \\
\hline Christian & 2016 & $\begin{array}{l}\text { Weakness, difficulty in respiratory process, and } \\
\text { difficulty after surgery are the sign and symptoms of } \\
\text { malnutrition. }\end{array}$ \\
\hline $\begin{array}{c}\text { Visvanathan and } \\
\text { Chapman }\end{array}$ & 2016 & $\begin{array}{l}\text { Low body temperature, slow and longer recovery } \\
\text { from infections }\end{array}$ \\
\hline Sami et al. & 2017 & Slow and longer recovery from infections \\
\hline
\end{tabular}

\section{Findings and Discussion}

Based on analysis the researcher find out that poor diet, mental health problems, mobility problems, digestive disorders are the causes of malnutrition. Such emerging concept was supported by [16] by indicating that poor diet and different health problems causes malnutrition among the children.

It was also find out by the present research study that low body temperature and improper recovery from illness as well as from injuries all sign and symptoms of malnutrition. Such findings were supported by study conducted by [17] according to the findings of their study, longer recovery from illness and low body temperature both are sign and symptoms of malnutrition. The study conducted by [18] also support the findings of the present study by concluding that weakness, difficulty in respiratory process difficulty after surgery and Low body temperature, slow and longer recovery from infections are earlier sign and symptoms of malnutrition

\section{Conclusion}

Based on the findings of previous research studies the researcher reached at conclusion that Poor diet, mental health problems, mobility problems, digestive disorders and stomach conditions, alcoholism etc all are the causes of malnutrition [19]. It was also concluded by the researcher from the available literature that loss of fat, difficulty in respiration, and complication during surgery are the main sign and symptoms of malnutrition. Furthermore, under nutrition can lead the body toward weakness and over nutrition lead the body toward obesity. 
Citation: Khan A, Khan S, Zia-ul-Islam S, et al. Causes, sign and symptoms of malnutrition among the children. J Nutr Hum Health. 2017;1(1):24-27.

\section{References}

1. NHS Choices. Malnutrition-Overview. Accessed on April 22, 2017.

2. Bruch H. Eating disorders: Obesity, anorexia nervosa, and the person within (Vol. 5052). Basic Books. 1973;5052.

3. Hoch AZ, Goossen K, Kretschmer T. Nutritional requirements of the child and teenage athlete. Phys Med Rehabil Clin. 2008.

4. US National Library of Medicine. Joint Collection Development Policy: Human Nutrition and Food. Accessed on April 04, 2017.

5. Australian Food Council. Nutrients-your body needs them! But, what are nutrients? 2011.

6. Schaffer C. Effects of malnutrition on the body. Merck manual online library. 2011.

7. De Onis M, Monteiro CA, Akre J, et al. The worldwide magnitude of protein-energy malnutrition: an overview from the WHO global database on child growth. Bull World Health Organ. 1993;71(6):703-12.

8. Nordqvist C. Malnutrition: Causes, Symptoms and Treatments. 2016.

9. Khan SU, Khan A, Khan S, et al. Perception of athletes about diet and its role in maintenance of sports performance. J Nutr Hum Health. 2017;1.
10. Visvanathan R, Chapman IM. Undernutrition and anorexia in the older person. Gastroenterol Clin North Am. 2009;38(3):393-409.

11. Kerstetter JE, Holthausen BA, Fitz PA. Malnutrition in the institutionalized older adult. J Am Diet Assoc. 1992;92(9):1109-16.

12. Rabiee F, Geissler C. Causes of malnutrition in young children: Gilan, Iran. J trop pediatr.1990;36(4):165-70.

13. Khan. Concept of sports training and coaching. LAP Germany. 2014.

14. Orphan nutrition. Impact of Malnutrition on Health and Development. Accessed on April 09, 2017.

15. Morley JE, Silver AJ. Nutritional issues in nursing home care. Ann Inter Med.1995;123(11):850-9.

16. Stratton RJ, Green CJ, Elia M. Disease-related malnutrition: An evidence-based approach to treatment. Cabi. 2003.

17. Tierney AJ. Undernutrition and elderly hospital patients: A review. J Adv Nurs. 1996;23(2):228-36.

18. Growth. Bulletin of the World Health Organization. 71:703-12.

19. Hoch AZ, Goossen K, Kretschmer T. Nutritional requirements of the child and teenage athlete. Phys Med Rehabil Clin. 2008.

\section{*Correspondence to:}

Alamgir Khan

Department of Sports Science and Physical Education Gomal University, KP

Pakistan

Tel: +919730796994

E-mail: alamgir1989@hotmail.com 